\title{
Comparative Structural Organization of Skin in Red-Tail Shark (Epalzeorhynchos Bicolor) and Guppy (Poecilia Reticulata)
}

\section{Doaa M Mokhtar*}

Department of Anatomy and Histology, Faculty of Veterinary Medicine, Assuit University, Egypt

\begin{abstract}
The surface architecture and histological organization of the skin of two ornamental fish; red-tail shark (Epalzeorhynchos bicolor) and guppy (Poecilia reticulata) were the main focus of this study. The skin of the two species was composed of epidermis, dermis and hypodermis, although the epidermis showed great variations in their components in the two species. The epidermis of red-tail shark was consisted of epidermal cells, mucous goblet cells, serous goblet cells, club cells, rodlet cells and melanocytes. While, the epidermis of guppy was composed of epidermal cells, mucous goblet cells, eosinophilic granular cells, lymphocytes and melanocytes. The skin of red-tail shark included a variety of sense organs as tuberous receptor organs in the head, superficial neuromasts on the lower lips and the head, canal neuromast in the operculum and the head, and taste buds on the lips, operculum, dorsum of the head and lateral regions of the trunk. However, the skin of guppy was characterized by presence of ampullary organ on the dorsal side of the head, superficial neuromasts on the lips and the head, canal neuromast in the operculum and the head, and taste buds on the operculum, dorsum of the head and trunk regions. These structural peculiarities with histochemical features indicate additional physiological role of the skin of the two species, as the mucous goblet cells in the two species contained a considerable amount of glycoconjugates, whereas the other unicellular gland types, the serous goblet cells and club cells in red tail shark were proteinous in nature. The dermis and hypodermis was consisted of connective tissue, mainly collagenous fibers. Scanning electron microscopy indicated presence of fingerprint like- patterns of microridges of the epidermal cells, pores for lateral canal system, openings of mucous cells and taste buds with specific sensory organs in each fish species.
\end{abstract}

Keywords: Epidermis; Guppy; Red tail shark; Scanning electron microscopy; Histochemistery; Lateral line system

\section{Introduction}

The skin of a fish is a multifunctional organ and may serve important roles in protection, communication, sensory perception, locomotion, respiration, excretion, osmoregulation and thermal regulation [1]. The skin is self active secretory organ that their cellular components provide many useful products. Goblet cells secrete mucus that keep the body surfaces moist and protect it from stressors [2], club cells produce the alarm substances that initiate the alarm reaction [3] and melanocytes produce pigments to provide the fish with specific colorations [4]. The skin is also a vehicle for coetaneous sense organs that allowed the fish for detection of predators and foods. Among them are taste buds and lateral line system that include neuromasts and electroceptive organs [5].

The skin of fish shows various inter-species difference, as some species have scales and others have special cells. The skin is composed of dermis and epidermis. The comparative anatomy of fish skin, especially the epidermis, has been investigated by light and electron microscopy $[6,7]$. However, less consideration have been given to the skin of both red-tail shark and guppy fish. Red tail shark (Epalzeorhynchos bicolor) is one of freshwater fish, belongs to family Cyprinidae that originates from the streams and waterways of Thailand. It is characterized by black body and orange tail and its skin is covered with transparent scales [8]. The guppy (Poecilia reticulata), also known as million fish and rainbow fish is one of the most popular freshwater aquarium fish species. It is a member of the Poeciliidae, whose natural range is in South America, were introduced to many habitats and are now found all over the world. The body of guppy is transparent and is covered with colorless scales and has ornamental dorsal and caudal fins. Guppies are used as a model organism in the field of ecology, evolution, and behavioural studies [9].

The aim of this study was to assess the morphology of skin at different parts of the body focusing on patterns of distribution of the sensory organs of red-tail shark and guppy fish with special reference to histochemistery of glycoconjugates and protein secreting cells (Figure 1).

\section{Materials and Methods}

\section{Samples collection}

The materials employed in this study were consisted of randomly obtained 16 adult specimens of males and females red- tail shark (Epalzeorhynchos bicolor) and guppy (Poecilia reticulata) that purchased from shops of ornamental fish. The mean standard length was $4.80 \pm$ $1.01 \mathrm{~cm}$ for red-tail shark and $3.05 \pm 0.8 \mathrm{~cm}$ for guppy. The fish were

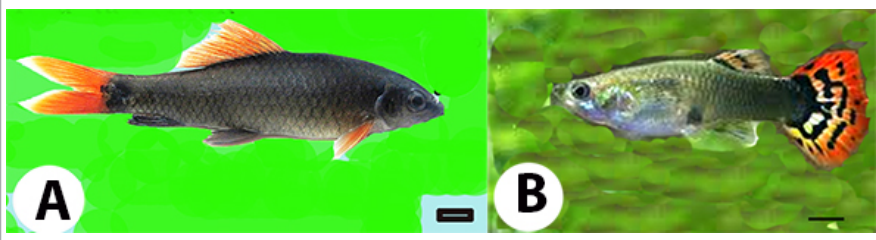

Figure 1: Showing red tail shark $(A)$ and guppy $(B) .($ Scale bar $=1 \mathrm{~cm})$

*Corresponding author: Doaa M Mokhtar, Department of Anatomy and Histology, Faculty of Veterinary Medicine, Assuit University, Egypt, E-mail: doaamokhtar33@yahoo.com

Received March 23, 2015; Accepted April 09, 2015; Published May 30, 2015

Citation: Mokhtar DM (2015) Comparative Structural Organization of Skin in RedTail Shark (Epalzeorhynchos Bicolor) and Guppy (Poecilia Reticulata) J Aquac Res Development 6: 345. doi:10.4172/2155-9546.1000345

Copyright: (c) 2015 Mokhtar DM. This is an open-access article distributed under the terms of the Creative Commons Attribution License, which permits unrestricted use, distribution, and reproduction in any medium, provided the original author and source are credited. 
deeply anaesthetized with benzocaine $(4 \mathrm{mg} / \mathrm{L})$ and decapitated. Pieces of skin from dorsum sides of head, snout, operculum, lips, lateral parts of the trunk regions and tail region were excised and rinsed in physiological saline.

\section{Histological and histochemical examination}

Samples for histological technique were dissected at $1 \times 1 \times .05 \mathrm{~cm}$ and were immediately fixed in Bouin's fluid for 22 hours. The fixed materials were dehydrated in an ascending series of ethanol, cleared in methyl benzoate and then embedded in paraffin wax. Serial sections of the entire fish at 5-8 $\mu \mathrm{m}$ in thickness were cut and stained with Harris haematoxylin and Eosin for general structure, Crossmon's trichrome for collagenous fibers. For carbohydrates histochemistry, sections were stained by combined Periodic Acid-Schiff (PAS) technique and Alcian blue ( $\mathrm{pH}$ 2.5). Representative sections were stained with bromophenol blue, performic acid-methylene blue and Mallory triple stain for detection of proteins [10].

\section{Morphometery}

Mean thickness of the epidermis $(\mu \mathrm{m})$ and density of mucous cells $/ 100 \mu \mathrm{m}$ of the epidermis in all selected regions in the two fish species were recorded \pm SE.

\section{SEM preparation}

The skin of all head regions of both species were immediately washed by $0.1 \mathrm{M} \mathrm{Na}$-cacodylate buffer. Then they were fixed in a mixture of $2.5 \%$ paraformaldehyde and $2.5 \%$ glutaraldehyde in $0.1 \mathrm{M}$ Na-cacodylate buffer, $\mathrm{pH} 7.3$ for 4 hours at $4^{\circ} \mathrm{C}$. Thereafter, they were washed in the same buffer used and post-fixed in $1 \%$ osmic acid in 0.1 $\mathrm{M} \mathrm{Na}$-cacodylate buffer for further 2 hours at room temperature. The samples were then dehydrated by aceton followed by isoamyl acetate and then subjected to critical point drying method with a polaron apparatus. Finally, they were coated with gold and observed with JEOL scanning electron microscope (JSM-5400 LV) at KV 10.

\section{Results}

The skin was composed of epidermis of non-keratinized stratified squamous epithelium with goblet cells, followed by dermis of dense regular connective tissue.

\section{Red-tail shark}

At the lower lip region: The epidermis was $51 \mu \mathrm{m}$ in thickness (Table 1) and consisted of stratified squamous epithelium noncornified that formed of a simple columnar epithelium lie on wavy thick basement membrane, on the top of these layers were several layer of eosinophilic club cells followed by squamous cell layers. Pear-shaped taste buds were observed at the top of the epidermis (Figure 2A). Large number of PAS-AB-positive mucous goblet cells was distributed at the superficial layers. The density of mucous cells was $12 / 100 \mu \mathrm{m}$ (Table 1). Club cells were large cells varied from spherical to saccular in shape and were negative to this stain (Figure 2B). The dermal layer was formed of dense compact parallel bundles of collagenous fibers. Aggregated melanocytes were located at the dermal margin as a continuous layer. The hypodermis was clearly organized layer of loose connective tissue (Figure 2A and 2B).

At the upper lip: The epidermis was thicker; $65 \mu \mathrm{m}$ (Table 1). Taste buds were distributed in this region as it occurred more frequently in the anterior parts of the body than posteriorly (Figure 2C and D). Mucous goblet cells occupied the superficial layers of epidermis that opened directly to the surface and stained positive with combined PAS-
$A B$ (Figure 2D). The density of mucous cells was 10/100 $\mu \mathrm{m}$ (Table 1).

At the snout: The epidermis was of less thickness; $44 \mu \mathrm{m}$ (Table 1) and characterized by large number of club cells in mid epidermal level and numerous PAS-positive mucous goblet cells. The density of mucous cells was $8 / 100 \mu \mathrm{m}$ (Table 1 ). Tuberous receptor organ was distributed at this region and appeared as spherical structure of sensory cells surrounded by a cellular capsule. Melanocytes were randomly distributed in the dermis (Figure 2E).

At the operculum: The epidermis was $42 \mu \mathrm{m}$ in thickness (Table 1). The mucous goblet cells were restricted on the superficial layer. The cells were positive with PAS-AB stain. The density of mucous cells was $8 / 100 \mu \mathrm{m}$ (Table 1). Taste buds were observed as pale staining, pearshaped structures consisting of columnar sustentacular cells with dark nuclei alternated with fusiform sensory cells with light nuclei and associated with small pyramidal basal cells and surrounded by marginal cells. Melanocytes were observed as a continuous layer at the dermal

\begin{tabular}{|l|c|c|c|c|}
\hline \multirow{2}{*}{ Body regions } & \multicolumn{2}{|c|}{ Red tail shark } & \multicolumn{2}{c|}{ guppy } \\
\cline { 2 - 5 } & $\begin{array}{c}\text { Thickness of } \\
\text { the epidermis } \\
(\boldsymbol{\mu m})\end{array}$ & $\begin{array}{c}\text { Density of } \\
\text { mucous } \\
\text { cells } \mathbf{1 0 0} \boldsymbol{\mu m}\end{array}$ & $\begin{array}{c}\text { Thickness of } \\
\text { the epidermis } \\
(\boldsymbol{\mu m})\end{array}$ & $\begin{array}{c}\text { Density of } \\
\text { mucous cells/ } \\
\mathbf{1 0 0} \boldsymbol{\mu m}\end{array}$ \\
\hline Lower lip & $51.3 \pm 4.1$ & $12.2 \pm 2.4$ & $36.1 \pm 2.3$ & $14.8 \pm 2.3$ \\
\hline Upper lip & $65.2 \pm 5.0$ & $10.5 \pm 2.7$ & $58.2 \pm 3.6$ & $12.0 \pm 2.3$ \\
\hline Snout & $44.5 \pm 3.9$ & $8.1 \pm 2.8$ & $38.6 \pm 3.0$ & $8.6 \pm 1.9$ \\
\hline Operculum & $42.2 \pm 2.8$ & $8.9 \pm 2.6$ & $30.8 \pm 1.9$ & $8.5 \pm 2.8$ \\
\hline Dorsum of head & $38.6 \pm 3.6$ & $8.3 \pm 1.4$ & $36.5 \pm 2.8$ & $10 \pm 1.8$ \\
\hline Trunk & $18.0 \pm 2.2$ & $4.5 \pm 1.0$ & $11.6 \pm 2.4$ & $6.3 \pm 1.3$ \\
\hline Tail & $40.5 \pm 3.7$ & $2.2 \pm 1.5$ & $39.4 \pm 4.4$ & $14.7 \pm 3.7$ \\
\hline
\end{tabular}

Table 1: The mean thickness of epidermis $(\mu \mathrm{m})$ at different body region and the density of mucous cells $/ 100 \mu \mathrm{m}$ of the epidermis in both fish species.

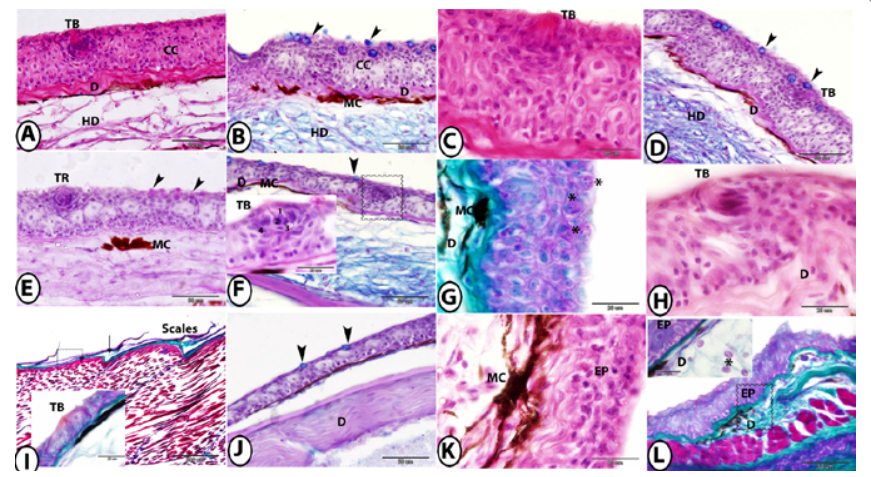

Figure 2: Organization of skin of red tail shark at different body regions. A and B: The skin of the lower lip stained by HE and PAS-AB-HX respectively showing taste bud (TB), club cells (CC), mucous cells (arrowheads) and melanocytes (MC) at the dermis (D) followed by hypodermis (HD). C and D: The skin of the upper lip stained by HE and PAS-AB-HX respectively showing taste bud (TB), mucous cells (arrowheads) and thin dermis (D) followed by hypodermis (HD). E: The skin of the snout stained by PAS-AB-HX showing PAS positive mucous cells (arrowheads), tuberous organ (TR) and melanocytes (MC). F: The skin of the operculum stained by PAS-AB-HX showing mucus cells (arrowhead), taste bud (square, TB, inserted figure) that consisted of sensory cells (1), supporting cells (2), basal cells (3) and mentle cells (4). Note, melanocytes (MC) on the dermis(D). $\mathbf{G}$ and $\mathbf{H}$ : The skin of the dorsum of the head stained by Crossmon's Trichrome and HE respectively showing rodlet cells (asterisk), taste bud (TB), melanocytes (MC) on the dermis (D) of collagenous fibers. I: The skin of the trunk stained by Crossmon's Trichrome showing scale pockets (arrow), taste bud (square, TB, inserted figure). J: Tigher magnification of square of figure. I showing the skin of trunk stained by PAS-AB-HX indicates positive stained mucous cells (arrowheads). Note parallel bundles of collagenous fibers in the dermis (D). K and L: The skin of the tail stained by HE and Crossmon's Trichrome respectively showing melanocytes (MC) in the deeper layers of epidermis (EP). The dermis $(\mathrm{D}$, inserted figure in $\mathrm{L}$ ) contained many rodlet cells (asterisk). 
margin. The dermis was composed of undulated compactly arranged collagenous bundles (Figure 2F).

At the dorsal aspect of the head: The mean thickness of the epidermis was $38 \mu \mathrm{m}$ and the density of mucous cells was $8 / 100 \mu \mathrm{m}$ (Table 1). Many rodlet cells were observed at the superficial layers as ovoid cells with basal nucleus and numerous cytoplasmic inclusions (rodlets). Large numbers of melanocytes were condensed at the superficial region of the dermis (Figure $2 \mathrm{G}$ ). Taste buds were observed at the superficial epidermal layer. The dermal region showed compactly arranged collagenous bundles (Figure $2 \mathrm{H}$ ).

At the trunk region: This region was covered with scales that originated from dermal scale-pockets and protrude posteriorly where they were covered by the epidermis. The epidermis was thinner $(18 \mu \mathrm{m})$ (Table 1) above the free portion of the scales. Bulb-shaped taste bud was demonstrated at the superficial region (Figure 2I). Few small spherical $\mathrm{PAS}-\mathrm{AB}$ positive mucous goblet cells were observed. The density of mucous cells was $4 / 100 \mu \mathrm{m}$ (Table 1). Melanocytes were observed as a continuous sheath. The dermis was formed of dense white regular collagenous connective tissue (Figure 2J).

At the tail region: The epidermis was thick; $40 \mu \mathrm{m}$ and the density of mucous cells was $2 / 100 \mu \mathrm{m}$ (Table 1 ). Highly branched melanocytes were distributed randomly throughout the deeper layers of the epidermis and in the dermis. These cells were filled with dark brown to black coarse granules (Figure $2 \mathrm{~K}$ ). The dermis was composed of collagenous bundles with many rodlet cells (Figure 2L).

\section{The guppy}

At the lower lip: The epidermis was $36 \mu \mathrm{m}$ in thickness and the density of mucous cells was $14 / 100 \mu \mathrm{m}$ (Table 1), it was consisted of stratified squamous epithelium non-cornified with highly mitotically active epidermal cells. The dermal region was formed of compact parallel bundles of collagenous fibers (Figure 3A).

At the upper lip: The epidermis was a thick $(58 \mu \mathrm{m}$, Table 1$)$, composed of stratified squamous epithelium non-cornfied. Mucous goblet cells were observed at the superficial layer of the epidermis. The density of mucous cells was $12 / 100 \mu \mathrm{m}$ (Table 1). Melanocytes were observed at the dermal margin (Figure 3B).

At the snout: The epidermis was $38 \mu \mathrm{m}$ in thickness and the density of mucous cells was $8 / 100 \mu \mathrm{m}$ (Table 1). Eosinophilic granular cells were spherical cells that occurred in the superficial layers of the epidermis. Their nuclei were eccentrically placed and their cytoplasmic granules stained bright red by HE. Lymphocytes were frequently distributed in the intercellular spaces of the deeper epidermal layers of this region and stained deep blue in HE (Figure 3C).

At the operculum: The epidermis was in $30 \mu \mathrm{m}$ in thickness (Table 1). The mucous cells were restricted on the superficial layer and were positive with PAS-AB stain. The density of mucous cells was $8 / 100 \mu \mathrm{m}$ (Table 1). Taste bud was observed in the superficial layer. The opercular core was formed of loose connective tissue and supported by strands of osteoid tissues. It was provided with well developed wide lateral canal (canal neuromast) (Figure 3D).

At the dorsal side of the head: The epidermis was $36 \mu \mathrm{m}$ in thickness (Table 1). The mucous cells were PAS-AB-positive and were restricted to the superficial layer of the epidermis (Figure $3 \mathrm{E}$ ). The density of mucous cells was $10 / 100 \mu \mathrm{m}$ (Table 1). Taste bud was also observed at this region. The dermis was formed of collagenous bundles (Figure 3F).
At the trunk: The trunk region was covered with scales that originated from scales pockets in the dermis. The epidermis above the scales was thin; $11 \mu \mathrm{m}$ (Table 1). It contained large number of PAS$\mathrm{AB}$ - positive mucous goblet cells with taste bud interspersed between the epidermal layer (Figure 3G). The density of mucous cells was $6 / 100$ $\mu \mathrm{m}$ (Table 1).

At the tail region: The mean thickness of the epidermis was $39 \mu \mathrm{m}$ (Table 1). Numerous PAS-AB- positive mucous goblet cells and large number melanocytes were observed (Figure $3 \mathrm{H}$ and I). The density of mucous cells was 14/100 $\mu \mathrm{m}$ (Table 1).

\section{The lateral line system}

Red tail shark: It was divided into 2 subsystems; mechanoreceptive neuromasts and electroreceptive tuberous receptor organs. The tuberous organ was more frequently occurred in the head region. The upper region of tuberous organ was covered by simple squamous epithelial cells. The tuberous organs contained 4-5 elongate nonciliated receptor cells within a cellular capsule. A single layer of supporting cells was present between the base of the receptor cells and the base of the capsule. A single thin nerve fiber innervates each group of organs (Figure $4 \mathrm{~A}$ and $4 \mathrm{~B}$ ).

2 types of neuromast present; canal (deep) and superficial neuromasts. Canal neuromasts were embedded in the dermis in form of tunnel-like canals. Large canal neuromasts were observed in the superficial layer of epidermis of the head and the operculum and

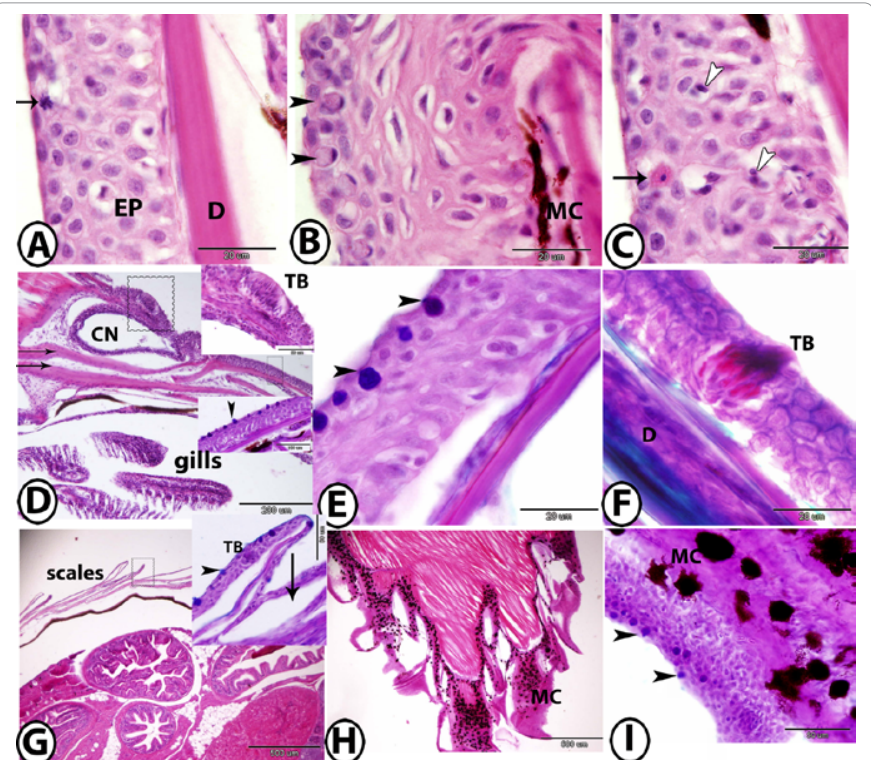

Figure 3: Organization of skin of guppy at different body region. A: The skin of the lower lip stained by HE showing mitotic cells (arrow) in stratified squamous epidermis (EP), followed by the dermis (D). B: The skin of the upper lip stained by $\mathrm{HE}$ showing mucous cells (arrowheads) and melanocytes (MC). C: The skin of the snout stained by HE showing eosinophilic granular cells (arrow) and lymphocytes (arrowheads). D: The skin of the operculum stained by HE showing taste bud (large square, TB). The small square indicates mucous cells (arrowhead) in the epidermis of the inserted figure stained by PAS-AB-HX. Note presence of canal neuromast (CN) surrounded by osteoid tissues (arrows). E and F: The skin of the dorsum of the head stained by PAS-AB-HX and Crossmon's Trichrome respectively showing mucous cells (arrowheads) and taste bud (TB). Note the dermis (D) is formed of collagenous fibers. G: The skin of the trunk stained by HE showing scale pockets (arrow). The square indicated the inserted figure stained with PAS-AB-HX showing taste bud (TB) and mucous cells (arrowhead). $\mathbf{H}$ and I: The skin of the tail stained by $\mathrm{HE}$ and PAS-AB-HX respectively showing numerous black melanocytes (MC) and many mucous cells (arrowheads) 
invested by dense fibrous wall without any cartilaginous support. It lined by stratified cuboidal epithelium and opened directly to the surface epithelium by a pore (Figure 4C and 4D). Large number of superficial neuromasts located at the lower lips and the head. Four main cell types encountered in the superficial neuromast; sensory hair cells, supporting cells, basal cells and surrounded by crescent shaped mantle cells. The superficial neuromast in many cases were covered by the cupula (dome of gelatinous materials) extending into the surface (Figure $4 \mathrm{E}$ and $4 \mathrm{~F}$ ).

Guppy: The lateral line system was divided into 2 subsystems; ampullary organ and neuromasts. The ampullary organs localized in the head region behind the eye, it ranged in size from $200-250 \mu \mathrm{m}$ in length and $100-125 \mu \mathrm{m}$ in diameter. It formed of specialized receptors. These receptors were generally ampoule- shaped, and their lumen opened to the surface by means of a short channel, the upper part of sensory cells was covered by a mucus-like substance called cupula. The sensory epithelium was found in a chamber situated in the basal portion of the epidermis or somewhat depressed into the dermis. The sensory epithelium of the organ was formed by 8 sensory cells. The sensory cells were pyriform in shape with dark cytoplasm with a large rounded centrally located nucleus and had microvilli on their apical surface with axon nerve endings in their basal part that arise from the underlying conjunctive tissue. Supporting cells were tall and narrow cells that completely enveloping the sensory cells with basally located



Figure 4: The lateral line system of red tail shark. A: Tuberous organ (square inserted figure) stained by HE that composed of sensory cells (1), supporting cells (2). B: Tuberous organs (arrow heads) stained by PAS-AB-HX are covered by flattened cells (arrows) and innervated by nerve fibers (asterisk). C and D: Cana neutomast (arrowheads) stained by HE surrounded by fibrous tissue (asterik). E: superficial neuromast (arrowhead) stained by HE formed of sensory cells (1) supporting cells (2), basal cells (3) and mantle cells (4). F: Superficial neuromast stained with Crossmon's trichrome showing attached cupula (arrowhead)

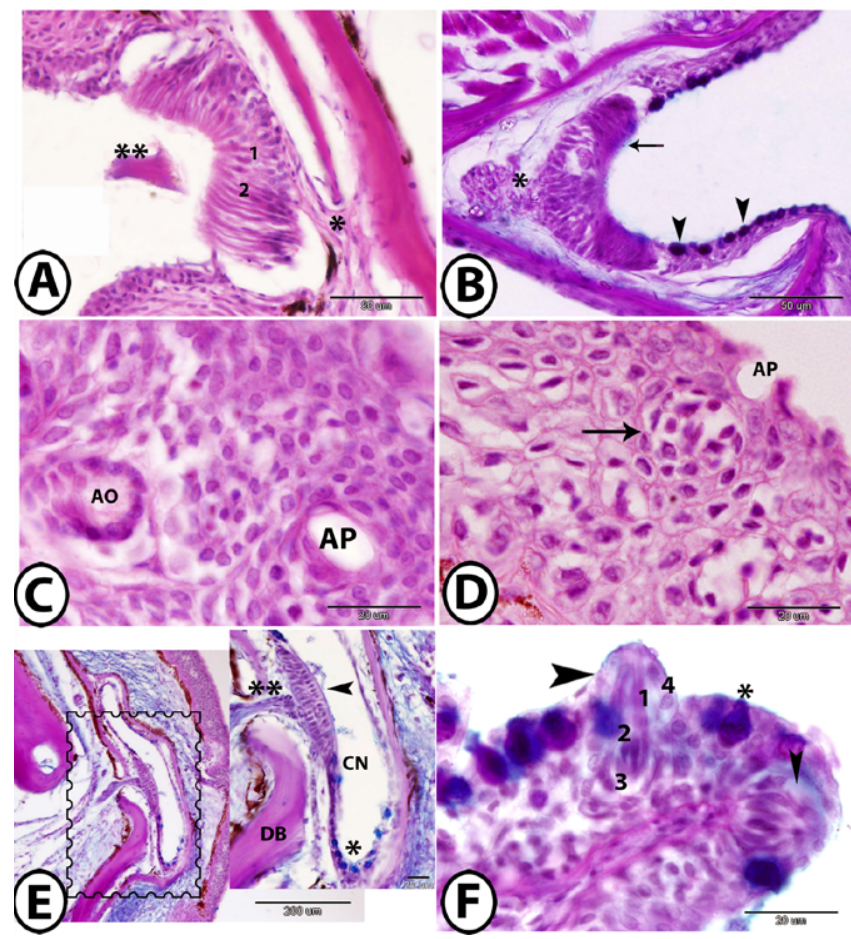

Figure 5: The lateral line system of guppy. A: the ampullary organ is formed of sensory cells (1), supporting cells (2) and covered by cupula (2 asteriks). Note presence of nerve fibers (asterisk) basally. B: ampullary organ stained with PAS-AB-HX showing AB-positive apical border of supporting cells (arrow), basal bundle of nerve fibers (asterik). Note that the ampullary channel contained PAS-AB positive mucous cells (arrowheads). C: a horizontal skin section of the epidermis stained by HE showing an ampullary pore (AP) in close proximity to an ampullary organ (AO). D: a vertical skin section stained with HE showing cross section of the ampullary organ (arrow) under an ampullary pore (AP). E: canal neuromast (square, inserted figure) stained with PAS-AB-HX showing the dermal bone (DB) that surrounded the canal neuromast $(C N)$, which lined by sensory cells (arrowhead), AB-positive mucous cells (asterisk). Note presence of nerve fibers (two asterisks) below the neuromast. F: Superficial neuromasts (arrowheads) stained by PAS-AB- HX is formed of sensory cells (1), supporting cells (2), basal cells (3) and surrounded by mentle cells (4). Note presence of mucous cells (asterisk) near neuromasts.

nucleus (Figure 5A and 5B). The canal of the ampullary organ contained mucous-cells that stained slight violet with PAS-AB stain, also theapical border of support cells were AB-positive (Figure 5B). The ampullary pores were distributed throughout the head and lined with a single layer of squamous cells (Figure 5C). Cross section of ampullary organ that formed of a sac of fusiform receptor cells was observed below the ampullary pore (Figure 5D).

The superficial and deep neuromasts differed from those present in red tail shark. The canals neuromast was widely distributed in the head and operculum and open at intervals to the exterior and surrounded by dermal bone. The canal neuromast was lined by two layers of sensory cells with apical microvilli and the opposite site of the canal was lined with a simple squamous epithelium containing $\mathrm{AB}$-positive mucus cells. Bundle of nerve fibers lie below the canal and passed between the dermal bones (Figure 5E). The superficial neuromast were concentrated in lips and the head. They rose above the surface epithelium and lined with sensory, supporting, basal cells and surrounded by mantle cells. Some mucus cells were present in the epithelium adjacent to the neuromast (Figure 5F).

Histochemical analysis to protein cells in red tail shark: Sacciform cells (serous goblet cells or protein sectreting cells): were encountered 
Citation: Mokhtar DM (2015) Comparative Structural Organization of Skin in Red-Tail Shark (Epalzeorhynchos Bicolor) and Guppy (Poecilia Reticulata). J Aquac Res Development 6: 345. doi:10.4172/2155-9546.1000345

in red- tail shark and they resembled the ordinary goblet cells and widely distributed in head and snout. They were pear-in shape and their cytoplasm stained deep red with Mallory triple stain, while the mucous goblet cells appeared blue with the same stain (Figure 6A and 6B). Also, sacciform cells appeared blue with bromophenol blue (Figure 6C) and deep blue with performic acid-methylene blue and the cell membrane appeared having an intensive reaction (Figure 6D). Histochemical analysis detected prevalence of protein within the cytoplasm of club cells rather than carbohydrates, as they were positive to bromophenol blue (Figure 6C).

\section{SEM}

Red- tail shark: Lateral line system and their associated pores based on their position around the head were categorized into infraorpital, supraorbital and otic lines (Figure 7A). Each canal neuromast opened as a pore in the skin of the head region (Figure 7B). The tuberous receptor organ formed of group of sensory cells that found in pits but was not covered by epidermis (Figure 7C). Microvilli projecting from the surfaces of the receptor cells were observed (Figure 7D). Superficial neuromast were noticed in the upper lips and dorsum of head localized mainly within the anteorbital area and may present as isolated elements or found in rows (Figure 8A). Each neuromast was sitting on an epidermal protrusion (Figure $8 \mathrm{~B}$ ). The epidermal protrusion was encircled with epithelial ring that showed shallow depression or invaginations to form a characteristic ring-like pattern. The top of the protrusion possessed hair bundles (Figure 8C). Neuromast with attached cupula was also observed (Figure 8D). Group of elevations were demonstrated in the dorsal surface of the head and appeared conical in shape (Figure $8 \mathrm{E}$ ). The apex of each elevation was characterized by the presence of taste buds that protruded above the epithelial surface. At the summit of this elevation, numerous closely packed microvilli were originated and short cilia were observed in the center (Figure 8F). The surface of the epidermal cells appeared polyhedral in shape bearing finger-print like microridges and interspersed by openings of mucous cells and melanocytes (Figure 8G). The broken surface of the epidermis indicated presence of large club cells and melanocytes with cytoplasmic processes (Figure $8 \mathrm{H}$ ).

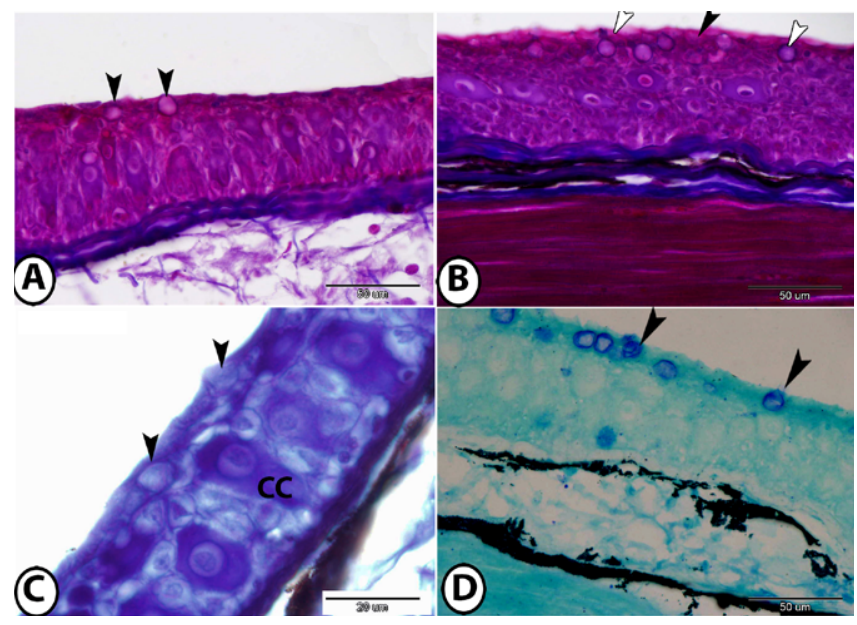

Figure 6: Histochemistery of protein secreting cells in red tail shark. A and B: The skin stained with Mallory triple stain showing red serous goblet cells (black arrowheads) and blue mucous goblet cells (white arrowheads). C: The skin stained with bromophenol blue showing serous goblet cells (arrowheads) and positive stained club cells (CC). D: The skin stained with Performic acidmethylene blue showing positive stained serous goblet cells (arrowheads).

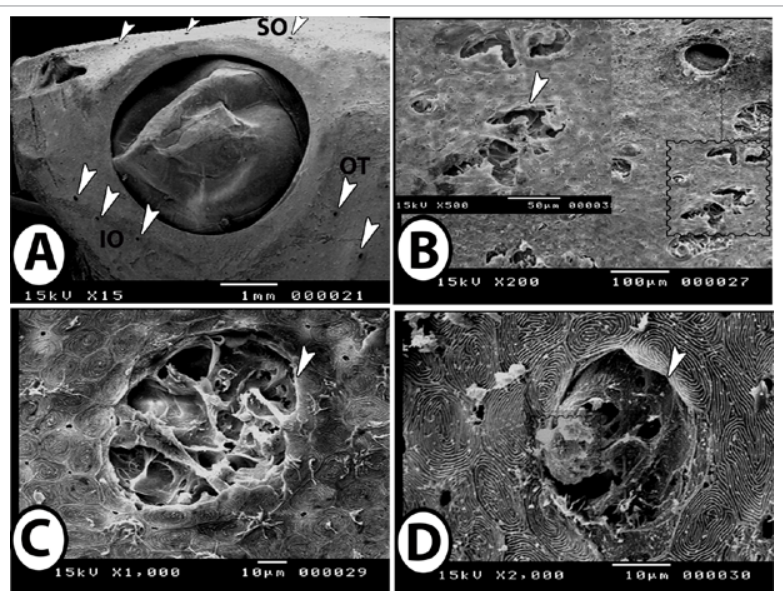

Figure 7: SEM of the lateral line system of red tail shark. A: The lateral line (arrowheads) branch in the head into supraorbital (SO), infraorbital (IO) and otic (OT). B: Pores of lateral lines (large square, inserted figure, arrowhead). C: Higher magnification of small square in Figure B showing tuberous receptor organ (arrowhead). D: Tuberous receptor organ (arrowhead) showing microvilli projecting from the receptor cells (square).

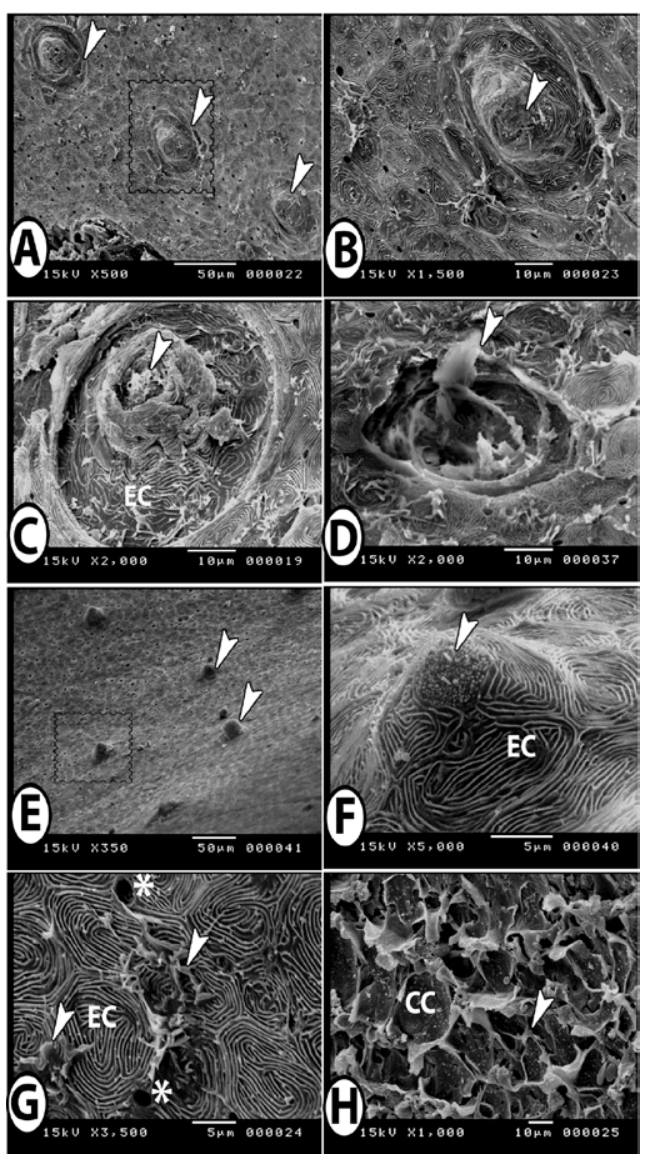

Figure 8: Neuromasts and taste buds of red tail shark. A: Superficial neuromasts arranged in rows (arrowheads). B: Higher magnification of the square in Figure A showing superficial neuromast (arrowhead). C: Ring like pattern of neuromast formed of epidermal cells (EC) with hairs from sensory cells at their apex (arrowhead). D: Superficial neuromast with attached cupula (arrowhead). E: Epidermal elevations (arrowheads, square). F: Conical non-keratinized protuberance of epidermal cells (EC) with a taste bud at a summit (arrowhead). G: surface of the epidermis showing epidermal cells (EC) with microridges, interspersed by opening of mucous cells (stars) and melanocytes (arrowheads). H: Broken surface of the epidermis showing club cells (CC) and melanocyte (arrowhead). 
The guupy: Lateral line system and their associated pores of guppies based on their position around the head were categorized into supraorbital, otic and preopercular lines (Figure 9A). The ampullary organ was localized within grooves or minute pores in the head region behind the eye beside the lateral line channels (Figure 9B). From the surface view, the ampullary organ appeared spherical with attached cupula (Figure 9C). In the lateral view, it appeared spherical with alveolilike appearance (Figure 9D). Ampullary pore distribution patterns were relatively unique, with the majority of pores occurring on the dorsal region of the head, which were analogous in location to the ampullary organs (Figure 9E). The diameter of ampullary pores ranged from 5-10 $\mu \mathrm{m}$. Superficial neuromasts with attached cupula were observed along the line of ampullary organ (Figure 9F). The surface of the epidermis was composed of polyhedral epithelial cells that were covered by fingerprint- like pattern microridges. The boundaries between cells were clearly defined (Figure 9E and 9F).

\section{Discussion}

The epidermis of both red- tail shark and guppy was consisted mainly of stratified squamous epithelium interspersed with mucous cells. The primary function of the epidermis is protection against environmental hazards. In fish, mucogenic cells generally provide this function by secreting their contents on the surface. The distribution of the mucus cells in the epidermis varied greatly in this study. In red tail shark, they were condensed at anterior body regions, reduced in trunk region and decreased in tail. Similar findings were found in the eels [11]. While in

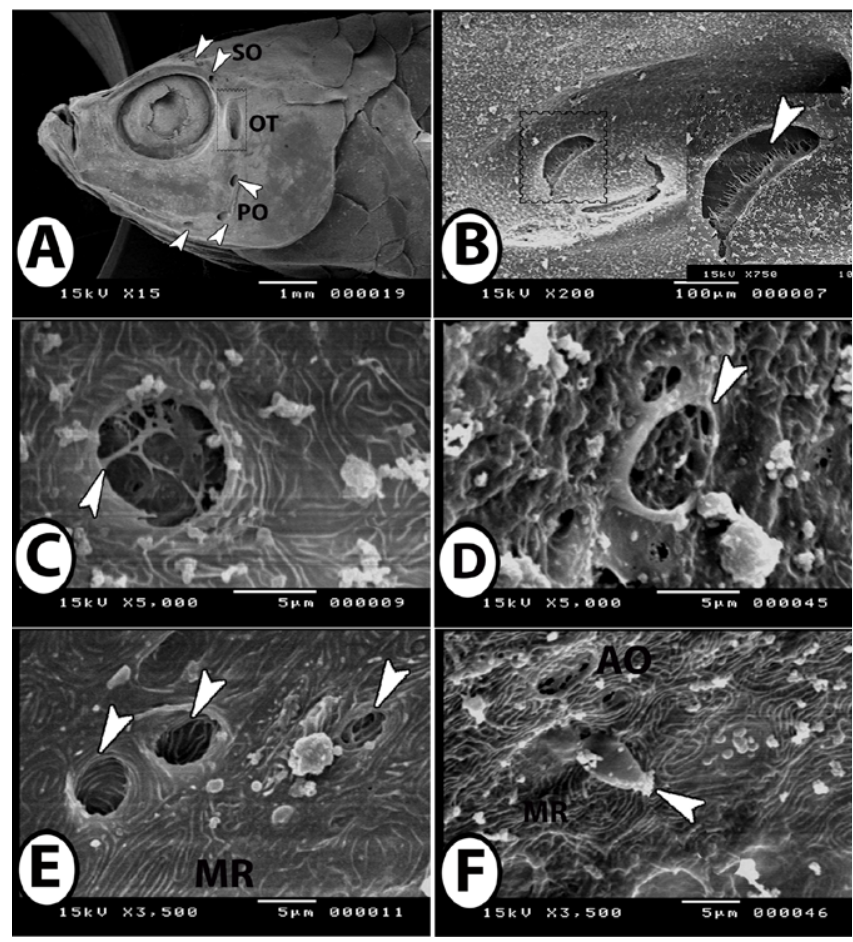

Figure 9: SEM of lateral line system of guppy. A: The lateral line branch in the head into supraorbital (SO), otic (square) and preopercular (PO). B: Higher magnification of the square in Figure A showing ampullary organ (square, inserted figure) in a pit in the skin of the head that formed of receptor cells (arrowhead). C: Surface view of ampullary organ with attached cupula (arrowhead). D: Lateral view of ampullary organ (arrowhead) with alveolar-like appearance of the organ. E: Different size and shapes of ampullary pores (arrowheads). Note presence of fingerprint-like microridges (MR) of the surrounding epidermal cells. F: Superficial neuromast with attached cupula (arrowhead) that occur near ampullary organ (AO) among microridges (MR) of epidermal cells. the guppy, the mucous cells condensed in anterior region and tail and decreased in trunk. The condensation of mucoid cells in the anterior body regions was very important in lubrication and protection of fish against abrasive injuries during searching of the foods from bottom. Furthermore, the mucus cells of both species were PAS-AB positive as the sulphate groups provide an acidification of glycoproteins, which was effective to prevent bacterial and viral invasion [12].

In the guppy, the mucous cells were numerous and are well developed, club cells are either rare or absent, whereas in red- tail shark the mucous cells were smaller in number and the club cells are numerous and well developed. Singh and Mittal [7] suggested that the low density of mucous cells is compensated by the high density of club cells as an effective defense mechanism. The club cells of red- tail shark secret protinous substances as they stained positive with bromophenol blue. Other authors believed that the club cells are related to production, storage and release of the alarm substance, leading to alarm reaction in phylogenetically close species [13], or suggested a phagocytic function [14]. Chondroitin and keratin were also found in cytoplasm of club cells of some fish, suggesting a healing function, thus helping on repair of damaged tissue [15]. Sacciform or serous goblet cells were encountered in the epidermis of red tail shark and were positive to protein stains. Sacciform and club cells have been interoperated recently as a storehouse of biologically active substances and have also been associated with specific functions such as defense [16].

Eosinophilic granular cells were demonstrated in the snout of guppy. The marked histological and biochemical similarity between fish eosinophils and mammalian mast cells has been noted by Powell, et al. [17] and suggested that they release toxic proteins and oxygen radicals onto the body surface of multicellular parasites in areas of inflammation.

Melanocytes increased in tail, lips, dorsum of the head in both species. Toledo and Jared [18] working on amphibian skin, suggested that the dermal chromatephore units provide patterns of coloration and may also function to absorb or reflect radiations (thereby contributing to regulation of body temperature). Their roles in coloration has been attributed to the presence of large numbers of a variety of pigmentcells types (chromatophores) that are present at different levels within the dermis, which include melanophores, xanthophores, erythrophores and iridophores. Melanophores are the most common class of fish pigment cells. The pigmented material of melanophores, called melanin, is deep brown in color. The melanophores are often star-shaped, of neuroectodermal origin. The coloration in fishes performs adaptative functions and is useful to the animal in a variety of ways such as camouflage, aggressive purpose and courting patterns [19].

Rodlet cells were encountered in the epidermis of the head region and dermis of red tail shark. Rodlet cells are commonly observed in tissues and organs of fish include kidney, gills, heart and gut [20]. The accurate function of these cells is unknown. Vickers [21] thought that they may be modified goblet cells. While Mattey, et al. [22], supposed a regulatory role of these cells in ion transportation and osmoregulation. These may also considered as non-specific immune cells, involved in immunity as their number is increased in parasitic infection [23]. Doaa and Hanan [24] supposed a secretory function to these cells with a holocrine mode of secretion.

The thickness of the epidermis is depending mainly on the number and size of the layers of the cells that constitute the epidermis at different body regions. In the present study, the lips and tail of both species have the highest epidermal thickness. SEM revealed presence of well 
organized fingerprint-like microridges of the surface of epidermal cells in both species that may provide structural integrity to the epithelium and increase the surface area as well as providing mechanical flexibility to the wall during distortion or stretching, retaining the mucus, facilitate the movement of materials over the surfaces and prevent physical abrasions. These observations confirm the finding of [25]. Taste buds are chemoreceptive organs and are characteristic features of fish skin and assist them in the recognition and location of food. Fishes are characterized by presence of widely distributed taste buds over various parts of the body include snout, lips, barbels, skin, gill rakers, oropharyngeal cavity and oesophagus of many fish species [26,27]. The present study revealed that in red tail shark, they were frequently observed in lips, operculum, head and trunk region and in guppy, they were found in the head, operculum and trunk region.

The lateral line is sensory system that allows fish to sense objects and motion in their local environment [28]. The lateral line system divided into 2 subsystems; mechanoreceptive neuromasts and electroreceptive ampullary and tuberous organs. 2 types of neuromast present in both species; superficial and canal neuromasts. Superficial one is sit on the skin surface and in direct contact with water, may present as isolated elements or found in rows that follow the path of lateral line system, while canal or deep neuromast occur under the skin within canals that contact the surrounding water via a series of small pores in the skin. Superficial neuromasts contain two cell types, hair cells or sensory cells and supporting cells [29]. Hair cells are basic transducers for sound, vibration, and in determining position in vertebrates [30]. The support cells encircle the hair cells and secrete a gelatinous-like material or "cupula" which covers the whole neuromast. The cupula enables the organ to communicate with the exterior [31] and it is involved in perception of the local water movements [32]. The results revealed that the canal neuromast of guppies were surrounded by ossois coat, while that of red tail shark were supported by fibrous coat and this may be adaptive mean against squeezing the contents of the canal by high water pressures in the bottom. Canal neuromasts of guppies contained $\mathrm{AB}$ positive mucous cells and this agreed with findings of Wark and Peiche [28] as these canals are filled with fluid (water and mucous secretion), which allow transmission of vibrations to the neuromasts through the skin pores. Several types of lateral line organs may thus exist in the same fish.

Tuberous organ was observed in red tail shark. It also encountered in some fish species as gymnotid [33] that play a significant role in sensation of weak electrical stimuli. They were consisted of sensory cells and covered by flattened cells to prevent the current from passing to the organ. Ampullary organs (or called electroreceptors) (formerly considered as neuromast) are found in the head region of guppy and also found in some fish and represent a morphologically and physiologically heterogeneous group of lateral line tonic receptors specialized in detecting the electromagnetic fields as well as temperature gradients [34]. The presence of the neutral mucosubstances that fill the ampulla along with the acid mucosubstances secreted by abundant mucous cells of the epidermis suggest that it may modulate the intensity of signals from receptor cells and/or give some protection and these materials have excellent electric conductivity. Several different biological functions of the ampullary electrosense have been proposed, including prey detection [35], detection of predators [36], social communication [36], detection of mates [37]. Moreover, the majority of morphological studies have assessed ampullary morphology via cross-section, while the use of scanning electron microscopy has been used very little. Ampullary organs have been classified into two different types based on the size and the length of the canals [38]. Wobbegong sharks possess 'macro-ampullae', which are characterised by large, visible pores and long canals of up to several centimeters in length that are common in marine environment. Whereas the 'mini-ampullae' of freshwater rays, with their microscopic size and short canals, are thought to be an adaptation to low conductivity within the freshwater environment [39]. SEM revealed alveolar like appearance of the ampullary organ of guppies. Within the different ampullary groups, variations in alveolar morphology exist and have been classified into five types based on alveolar arrangement: single-alveolate, multi-alveolate, branched alveolate, centrum cap and club-shaped. Ampullary organ differed in structures from species to species and this difference resulted from different environmental conductivity. The morphological analysis and a comparison of the different distribution patterns are used to infer how electroreception may participate in natural feeding behaviour, as well as possible adaptations of electroreception to the respective habitat types of each species.

\section{References}

1. Hawkes JW (1974) The structure of fish skin I. general organization. Cell Tissue Res 149: 147-158.

2. Gona O (1979) Mucous glycoprotein of teleostean fish. A comparative histochemical study. Histochemistery 11: 709-718.

3. Damasceno EM, Monteiro JC, Duboc LF, Dolder H, Mancini K (2012) Morphology of the Epidermis of the Neotropical Catfish Pimelodella lateristriga (Lichtenstein, 1823) with Emphasis in Club Cells. Plos One 7: 1-7.

4. Takeuchi IK (1967) Electron microscopy of two types of reflecting chromatophores (iridophores and leucophores) in the guppy, Lebistes reticulatus Peters. Cell and tissue research 173: 17-27.

5. Jakubowski M (1974) Structure of lateral system and related bones in Bery-coid fish (hoplostetus mideteraneous L.). Acta Anatomica 87: 261- 274.

6. Imaki H, Chavin W (1984) Ultrastructure of mucous cells in the sarcopterygian integument. Scanning Electron Microscopy 1: 409-422.

7. Singh SK, Mittal AK (1990) A comparative study of the epidermis of the common carp and the three Indian major carp. J Fish Biology 36: 9-19.

8. Yang JX, Winterbottom R (1998) Phylogeny and zoogeography of the cyprinid genus Epalzeorhynchos Bleeker (Cyprinidae: Ostariophysi). J Copeia 1: 48-63.

9. Anne ME, Dawn PAT (2001) Evolutionary implications of large-scale patterns in the ecology of Trinidadian guppies, Poecilia reticulata. Biol J Linn Society 73: $1-9$.

10. Bancroft JD, Gamble M (2002) Theory and Practice of Histological and Histochemical Techniques.

11. Gattas SM, Yanai T (2010) Light microscopical study on the skin of European eel (Anguilla Anguilla). World J Fish Marine Sci 2: 152-161.

12. Mittal AK, Ueda T, Fujimori O, Yamada K (1994) Histochemical analysis of glycoproteins in the unicellular glands in the epidermis of an Indian fresh water fish Mastacembelus panculus (Hamilton). Histochemistry J 26: 666-677.

13. Smith RJF (1992) Alarm signals in fishes. Rev Fish Biology and Fish 2: 33-63.

14. Lufty RG (1964) Studies on the epidermis of the catfish Synodontis schall. Sch Ain Shams Sci Bull Cairo 10: 153-163.

15. Iger $Y$, Abraham M (1990) The process of skin healing in experimentally wounded carp. J Fish Biology 36: 421-437.

16. Yashpal M, Mittal AK (2014) Serous goblet cells: The protein secreting cells in the oral cavity of a catfish, Rita rita (Hamilton, 1822) (Bagridae, Siluriformes). Tissue and cell 46: 9-14

17. Powell MD, Wright GM, Burka JF (1993) Morphological and distributional changes in the eosinophilic granular cells (EGC) population of the rainbow trout (Oncorhynchus mykiss Walbaum) intestine following systemic administration of capsacin and substance P. J Exp Zool 266: 19-30.

18. Toledo RC, Jared C (1993) Cutaneous adaptations to water balance in 
Citation: Mokhtar DM (2015) Comparative Structural Organization of Skin in Red-Tail Shark (Epalzeorhynchos Bicolor) and Guppy (Poecilia Reticulata). J Aquac Res Development 6: 345. doi:10.4172/2155-9546.1000345

amphibians. Comp. Biochem. Physiology 105: 593-608.

19. Kottler VA, Koch I, Flo“tenmeyer M, Hashimoto H, Weigel D (2014) Multiple Pigment Cell Types Contribute to the Black, Blue, and Orange Ornaments of Male Guppies (Poecilia reticulata). PLoS One 9: 85647.

20. Manera M, Dezfuli BS (2004) Rodlet cells in teleosts: a new insight into their nature and functions. Fish Biology 65: 597-619.

21. Vickers $T$ (1962) A study of the intestinal epithelium of the goldfish Carassius auratus: its normal structure, the dynamics of cell replacement and the changes induced by salts of cobalt and manganese. Q J Microsc Sci 103: 93-110.

22. Mattey DL, Morgan M, Wright DE (1979) Distribution and development of rodle cells in the gills and pseudobranch of the bass, Dicentrarchus labrax (L). J Fish Biology 15: 363-370.

23. Reite OB (2005) The rodlet cells of teleostean fish: their potential role in host defense in relation to the mast cells/eosinophilic granule cells. Fish Shellfish Immunolgy 19: 253-267.

24. Mokhtar DM, Abd-Elhafeez HH (2014) Light- and electron-microscopic studies of olfactory organ of Red-tail shark, Epalzeorhynchos bicolor (Teleostei: Cyprinidae). J Micr Ultras 2: 182-195

25. Gamal AM, Elsheikh EH, Nasr ES (2012) Morphological adaptation of the buccal cavity in relation to feeding habits of the omnivorous fish Clarias gariepinus: A scanning electron microscopic study. Basic Appl zool 65: 191-1980

26. Harvey R, Batty RS (1998) Cutaneous taste buds in cod. Fish Biology 53: 138-149.

27. Enas A Abd El Hafez, Mokhtar DM, Abou-Elhamd AS, Hassan AHS (2013) Comparative histomorphological studies on oesophagus of catfish and grass carp.

28. Wark AR, Peiche CL (2010) Lateral line diversity among ecologically divergent three spine stickleback Populations. J Expl Biol 213: 108-117
29. Ghysen A, Dambly-Chaudie're C (2004) Development of the zebrafish lateral line. Curr Opin Neurobiology 14: 67-73.

30. Kornblum HI, Corwin JT, Trevarrow B (1990) Selective labeling of sensory hair cells and neurons in auditory, vestibular, and lateral line systems by a monoclonal antibody. J Comparative Neurology 301: 162-170.

31. Cernuda-Cernuda R, Garcia-Fernandez JM (1996) Structural diversity of the ordinary and specialized lateral line organs. Micr Res Tech 34: 302-312.

32. Mukai Y, Yoshikawa H, Koboyashi H (1994) The relationship between the length of the cupulae of free neuromasts and feeding ability in larvae of the willow shiner Gnathopogon elongatus caerulescens (Teleostei. Cyprinidae). J Experimental Biology 197: 399-403.

33. Wachtel AW, Bruce- Szamier R (1966) Special cutaneous receptor organs of fish: The tuberous organs of Eigenmannia. J Morphology 119: 51-80.

34. Whitehead DL, Tibbetts IR, Daddow LYM (2003) Microampullary Organs of a Freshwater Eel-Tailed Catfish, Plotosus (tandanus) tandanus. J Morphology 255: 253-260.

35. Kalmijn AJ (1971) The electric senses of sharks and rays. J Experimental Biology 55: 371-383.

36. Sisneros JA, Tricas TC, Luer CA (1998) Response properties and biological function of the skate electrosensory system during ontogeny. J Comparative Physiology A 183: 87-99

37. Tricas TC, Michael SW, Sisneros JA (1995) Electrosensory optimization to conspecific phasic signals for mating. Neuroscience Lett 202: 129-132

38. Andres KH, Van-During M (1988) Comparative anatomy of vertebrate electroreceptors. Prog Brain Res 74: 113-131.

39. Szabo T, Kalmijn AJ, Enger PS, Bullock TH (1972) Microampullary organs and a submandibular sense organ in the freshwater ray, Potamotrygon. Comparative Physiology 79: 15-27 